NBER WORKING PAPER SERIES

\title{
DO BUDGET RULES WORK?
}

James M. Poterba

Working Paper 5550

\author{
NATIONAL BUREAU OF ECONOMIC RESEARCH \\ 1050 Massachusetts Avenue \\ Cambridge, MA 02138 \\ April 1996
}

This paper was prepared for the Burch Center Symposium, UC-Berkeley, February 2-3, 1996. I am grateful to Alan Auerbach, Doug Bernheim, David Cutler, Robert Reischauer, and David Romer for helpful comments and discussions, and to the National Science Foundation for research support. This paper is part of NBER's research program in Public Economics. Any opinions expressed are those of the author and not those of the National Bureau of Economic Research.

(C) 1996 by James M. Poterba. All rights reserved. Short sections of text, not to exceed two paragraphs, may be quoted without explicit permission provided that full credit, including (C) notice, is given to the source. 


\title{
DO BUDGET RULES WORK?
}

\begin{abstract}
The design of budget rules and institutions, long a neglected area in public finance and macroeconomics, has recently been thrust to center stage by the debate over a balanced budget amendment and other deficit-reduction measures in the United States. This paper describes the existing evidence on how budget rules affect fiscal policy outcomes. It contrasts the "institutional irrelevance view," which holds that budget rules can be circumvented by modifying accounting practices and changing the nominal timing or other classification of taxes and expenditures, with the "public choice view" in which fiscal institutions represent important constraints on the behavior of political actors. Several distinct strands of empirical evidence, from the U.S. federal experience with anti-deficit rules, from U.S. state experience with balanced budget rules, and from international comparisons of budget outcomes in nations with different fiscal institutions, suggest that fiscal institutions do matter. These results reject the institutional irrelevance view. The existing evidence is not refined enough, however, to provide detailed advice on how narrowly-defined changes in budget rules might affect policy outcomes.
\end{abstract}

James M. Poterba Department of Economics, E52-350

MIT

50 Memorial Drive

Cambridge, MA 02139-4307

and NBER 
Many public finance economists have historically viewed budget rules as institutional details that do not warrant substantial research attention. With several notable exceptions, including Musgrave (1939), Colm and Wagner (1963), and Kotlikoff (1986), the discussion of budget policy has focused on optimal levels of expansionary or contractionary policy, or the design of tax and expenditure programs, as though an all-powerful social planner could modify policy precisely in accord with economists' recommendations. The potential role for budget institutions in affecting policy outcomes has received relatively little investigation.

In the social planner paradigm, arbitrary budget restrictions such as balanced-budget rules or tax and expenditure limits represent constraints that can not improve, and may reduce, social welfare. One positive theory of government deficits, formalized by Barro (1979), views deficits and surpluses as the outcome of a social planner's tax smoothing problem. In this setting, a balanced-budget rule that requires taxes to equal spending would reduce welfare by preventing the social planner from choosing the optimal time path of taxes.

Actual budget deliberations may deviate in critical ways, however, from the stylized setting of the social planner paradigm. For example, if democratic budget processes exhibit a bias toward excessive spending and toward deficit finance, then the welfare cost of sub-optimal tax timing must be weighed against the welfare gains associated with constraining policy outcomes along 


\section{2}

other dimensions. It is precisely this possibility that is advanced by many of those who support the enactment of various types of fiscal limits. Alternatively, if the budget process is myopic, and places too much weight on the current cost of a project, regardless of its benefit stream, then long-lived capital projects may face more difficult political battles than short-run projects. This possibility is suggested by those who advocate adopting a separate capital and operating budget for the U.S. federal government.

Although theoretical models that permit detailed analysis of the impact of budget reforms have yet to be developed, there has been much speculation and some empirical research on the potential effects of different fiscal institutions. Blue-ribbon panels, such as the President's Commission on Budget Concepts (1967), have periodically considered the nature of existing budget rules and made suggestions for reform. A substantial volume of academic research has focused on defining "the" appropriate budget concept. Static, cash-accounting measures of budget deficits are widely recognized as imperfect measures of government fiscal stance, and a number of alternatives to current deficit measures have been developed. Among the modifications that have been considered are distinguishing between capital and operating expenditures with an explicit capital budget, recognizing implicit liabilities and more generally treating budget accruals as well as cash transactions, and expanding the budget horizon to provide information on fiscal balance over horizons longer than a 
single year. Another line of research does not focus on the definition of the budget as much as on the process by which the budget is enacted. This work, which is based on research in positive political economy, implies that changes in the structure of the budget process such as enactment of a line-item veto or requirement of a supermajority in Congress to enact budgets with deficits of a given size, implicitly or explicitly suggests that reforms to budget process could affect policy outcomes.

The central issue for economic policy is whether changing the yardstick that is used to assess fiscal policy, or the rules of the budget enactment process and the relative political power of those who participate in it, would affect budget outcomes such as the level of government spending or the fiscal deficit. It is difficult to bring convincing empirical evidence to bear on this issue for at least two reasons. First, some proposals currently under debate at the federal level involve budgetary innovations that have not been tried on a national or sub-national scale before. Second, there is relatively little variation over time, within nations, in the nature of their budget processes or in the set of summary statistics that are the center of budget debates. It is therefore difficult to compare fiscal policy before and after significant institutional reforms of the type that are currently under discussion.

In spite of these difficulties, there are some opportunities to study the effect of budget rules. One is the U.S. experience with Gramm-Rudman- 
Hollings (GRH), the anti-deficit legislation enacted in the mid-1980s. Another is provided by the variation in budget rules across states within the United States. Yet a third possible source of evidence arises from differences across nations in budget outcomes and budget policies, particularly within otherwise homogenous groups of nations. Some analysts are understandably hesitant to draw strong conclusions from cross-national comparisons because of the difficulty in holding constant other factors that might affect fiscal institutions.

One potential difficult confronting research in this area is that the term "budget rules" refers to a wide range of fiscal institutions. Examples include, but are not limited to, tax and expenditure limits at the local or state level in the United States, anti-deficit rules that restrict the power of state governments to borrow and carry-over budget shortfalls from one year to the next, and restrictions on the type of debt that can be issued without voter approval. Even the institutions that legislatures use to prepare budgets, and the structure of committees through which budget deliberations must proceed, can be viewed as budget rules. The wide variation in budget rules makes it difficult to draw any uniform conclusions about the effect of such rules on policy outcomes.

This paper draws together the limited evidence that has emerged from various research programs on the impact of budget rules. The preponderance of this evidence suggests that these rules matter, although the results do not permit refined judgements about the impact of specific provisions in budget 
policy. The paper is divided into five sections. The first provides a framework for discussing budget institutions, and considers the fundamental question of whether budget institutions can be viewed as anything more than a summary statistic for voter preferences. This section argues that with careful attention to the source of budget rules, it is possible to find exogenous variation in these rules and to use this variation as a source of information on how rules affect policy outcomes.

The second section discusses the U.S. experience since the enactment of federal anti-deficit legislation in the mid-1980s and early 1990s. It considers both the effect of this legislation on the level of taxes, spending, and deficits, as well as evidence on how the budget enactment and evaluation process has been affected by this legislation. Section three presents related evidence based on the experience of the United States states with anti-deficit rules and tax and expenditure limits. The fourth section discusses international evidence on the effect of budget rules and other fiscal institutions on deficits and the level of government indebtedness, referring to both developed and developing nations.

There is a brief conclusion, which suggests a number of points about the research agenda on budget institutions.

\section{A Framework for Analyzing Budget Rules}

Two recent developments have stimulated growing interest in fiscal 
institutions. First, there are evident differences in the size and persistence of budget deficits across nations. These do not seem obviously related to shortterm spending needs, such as wars, or to intertemporal variation in the marginal cost of raising revenue, as theories of optimal debt policy such as Barro (1979) would suggest. The inability to explain cross-national differences solely in terms of economic factors has led to a search for other factors, notably politicoeconomic explanations for deficit policies. Roubini and Sachs (1989) are one of the first studies in the modern revival to explore how political institutions such as the presence or absence of divided government affect fiscal policy outcomes.

The second factor driving recent interest in fiscal institutions is the rise of large peace-time budget deficits in the United States during the late 1970s and even more during the 1980s. The possibility that fiscal policy is biased toward deficit finance, and toward spending that yields concentrated benefits and diverse costs that nevertheless exceed the benefits, has been recognized for decades. Buchanan and Wagner (1977) and Weingast, Shepsle, and Johansen (1981) are relatively recent statements of these central points. Yet until the early 1980s, fiscal deficits in the United States and most other developed nations had been relatively small except during wars or deep economic downturns. As Poterba (1994a) and others have noted, the substantial tax cuts of 1981 and the failure to achieve the spending reductions 
that President Reagan had promised would coincide with these tax reductions led to unprecedented peace-time deficits. The rise of such deficits was the proximate cause of the discussion, beginning in the mid-1980s, of a federal balanced budget amendment, and of the related enactment of the GrammRudman-Hollings anti-deficit legislation. To evaluate the potential effects of such fiscal rules, public finance and macroeconomists have embarked on new research programs that draw substantially on previous work in positive political theory and in public administration.

\subsection{What Role Do Budgets Play?}

Economic research on budget institutions has taken three forms. The oldest line of inquiry asks "what are budgets for?," and considers issues of budget measurement and definition. Budgets can serve at least three functions: to inform the budget debate, to structure the debate on government programs, and to affect fiscal policy outcomes. With respect to information provision, it is possible to envision budgets defined over various horizons, with the nearestterm measuring the government's expenditures and revenues in only the current period, and the longest-horizon measure describing the present discounted value of government outlays and revenues under current or projected policies. The current horizon for most aspects of the federal budget process is five years, although political maneuvering in 1996 has involved promises of budget balance 
by 2002 , so a longer horizon. There are examples, such as the annual report produced by the trustees of the Social Security system, of much longer budget horizons. In the Social Security case, projections of cash flows and account balances for seventy-five years are presented each year.

With regard to structuring debate, the budget has important effects along many dimensions. Many features of actual budgets, such as the distinction between on- and off-budget programs, the categorization of spending into mandatory and discretionary, the "pay as you go" requirement that certain programs be fully funded when enacted, and even the sequencing of approval of overall budget targets (the budget resolution) and individual appropriation measures, affect the debate on government programs and on revenue sources. The information provision and debate-structuring role of budgets are clearly linked together, in that with multiyear budgets it is possible to consider a wider range of "budget balance" concepts than with a single year's account.

The final role of budgets, to affect fiscal policy outcomes, has attracted the most attention in recent policy discussions of balanced budget rules. The central objective of such reforms is to affect the relative likelihood of some budget outcomes vis-a-vis others. Tax limitation laws and requirements for popular approval of debt issues at the state level are examples of similar budgeting rules that are explicitly designed to reduce spending and tax levels relative to the size of the private economy. 


\subsection{How Do Budget Rules Affect Outcomes}

A second line of research on budgets has built on the recent advances in positive political economy to provide theoretical insights into the effect of budget institutions. This literature is directed toward a range of questions relating to the "industrial organization" of the legislature and the budget process, such as whether it matters if legislators vote first on the size of the budget and then on its allocation across spending programs, or vice versa. The findings of this literature are often sensitive to modelling assumptions. Ferejohn and Krehbiel (1987) illustrate this difficulty with respect to the timing of votes on budget size and allocation. They show that provided legislators form rational expectations about the allocative stage of the budget game, reversing the timing of the budget votes will not have any effect on fiscal policy outcomes. Masia (1995) presents a related analysis of how budget institutions can alter the political power of the executive, and how this can affect the nature of budgetary bargains.

One explanation of the role of budget rules, which has not been emphasized in the political economy literature to date, is that these rules provide a form of "self control" for political actors. If society exhibits dynamically inconsistent preferences with respect to fiscal policy, always preferring a larger budget deficit in the current period than it would have agreed to in previous periods, then budget rules may provide a mechanism for 
constraining the discretion of future budget deliberators. Laibson (1994) discusses a similar set of issues with respect to individual saving behavior. He suggests that in the presence of hyperbolic discounting, individual preferences with respect to saving will be time inconsistent, and that individuals may develop institutions that restrict their future ability to consume. Formal analysis of budget rules in a framework such as this, while promising, remains an issue for future research.

\subsection{Empirical Evidence on the Effects of Budget Rules}

The final strand of research on budget institutions has taken an empirical tack, analyzing how various rules for developing, enacting, and enforcing budgets affect the nature of fiscal policy. This work has exploited differences across nations, differences across states within nations, and differences within nations over time, to search for effects of budget rules on fiscal outcomes. A number of studies in this tradition have identified substantial effects of fiscal rules; this is the primary subject of this paper.

The central empirical problem in the research program on fiscal institutions and their effects is the potential endogeneity of budget institutions. Riker (1980) argues that essentially all political institutions reflect the "congealed preferences" of the electorate. In this view, institutions that no longer suit a majority of the electorate will be overturned, and the institutional 
structure of a nation or state contains no information other than some aggregation of information on current voter preferences. Skidmore and Alm (1994) demonstrate that state fiscal conditions, notably the level of state taxes, are related to the probability that voters will pass a tax limitation law; this underscores the institutional endogeneity problem for budget rules.

The institutional endogeneity problem with respect to budget deficits is similar to the problem that has plagued the macroeconomic research program on the effects of central bank independence. Posen (1995) argues that whether or not a central bank is independent is largely explained by the degree of opposition to inflation in the financial community within a nation. This suggests that the independence of the central bank cannot be viewed as an exogenous variable for explaining outcomes such as a nation's inflation rate.

With respect to budget institutions, the counter-argument to the institutional endogeneity view emphasizes the difficulty of changing these institutions, and the costs of revising fiscal rules. Alesina and Perotti (1995) argue that at least some of the international differences in budget rules should be viewed as exogenous. The difficulty associated with changing the federal budget process is evidence for this view, as is the fact that in many of the U.S. states, the current budget institutions are those that were established when the state joined the union.

There are at least two ways to reduce, if not solve, the problem of 
endogenous fiscal institutions. One strategy is to control for some measure of voter preferences, such as the political party of elected officials, or an objective index of voter preferences on the political spectrum. This reduces the potential for observed correlations between budget rules and fiscal outcomes to simply reflect a correlation of both of these variables with an omitted third variable, voter tastes for fiscal outcomes. The difficulty with this approach is that any set of control variables may not completely capture the potential omitted variables that underlie spurious findings.

A second approach involves modelling the evolution of budget rules, and using variables that affect budget rules but not fiscal policy as instrumental variables in a simultaneous equations econometric framework. The difficulty with this approach is finding valid instruments. While it is unlikely that any instruments will be beyond dispute, this approach provides a potentially promising method of addressing the institutional endogeneity problem. Exploiting these strategies represents an important part of the empirical agenda for research on budget institutions.

\section{U.S. Federal Experience With Deficit Limitation Laws}

The U.S. experience with anti-deficit rules in the mid-1980s and early 1990s represents one of the clearest cases of change in budget institutions at a national level, and therefore provides one of the best opportunities for learning 
about the potential effects of such reform. This section considers the impact of these anti-deficit rules. It begins with a brief overview of the time path of federal deficits, then describes the experience since the enactment of GrammRudman-Hollings in the mid-1980s and the Budget Enforcement Act of 1990.

\subsection{Federal Deficit Experience: The Postwar Period}

Table 1 shows federal budget deficits for the postwar period. The table includes both "on budget" deficits, which exclude the net surplus or deficit in the Social Security and Postal Service trust fund accounts, as well as the total deficit. The table shows that the total deficit as a share of GDP averaged $0.7 \%$ between 1950 and 1974 , but then increased to $3 \%$ of GDP between 1975 and 1979. One of the many potential explanations for this apparent change in the level of the deficit was a change in the internal organization of Congress in the late 1960 s and early 1970 s. A variety of institutional reforms reduced the power of committee chairs and central party leadership, "democratizing" Congress and granting increased power to individual members. The Budget and Impoundment Act of 1974 is the most extreme example of this type with respect to budget process, since it altered the relative power of the chairs of committees concerned with appropriations and the chairs of the Appropriations and Ways and Means committees. This may have resulted in growing support for spending programs with specific benefits but diffuse costs. 
Deficits became substantial in the late 1970s, but in the aftermath of the tax reductions in the Economic Recovery Tax Act of 1981 and the Reagan defense build-up, they became even more pronounced in the early 1980 s. The federal deficit peaked at $6.3 \%$ of GDP in fiscal year 1983 . The total deficit as a share of GDP has declined since then, falling to $2.9 \%$ of GDP in 1989 and, after increasing again during the recession of the early 1990 s, to $3.1 \%$ for fiscal 1994. Table 1 also shows that the on-budget deficit has not declined as sharply as the total deficit, which reflects the substantial surplus $10.8 \%$ of GDP for fiscal 1995). This is due largely to the substantial surpluses currently being accumulated in the Social Security trust fund.

The apparent reduction in deficits that the data in Table 1 suggests is often cited as an illustration of the difficulties posed by annual budget measures. Auerbach (1995) explains that changing demographics, coupled with rising relative costs of many of the services that governments in the United States are committed to purchase, imply a rising path of deficits as a fraction of GDP prospectively, even though current period and near-term deficit projections suggest some improvement in the fiscal situation. Focusing on longer-term measures of budget policy could thus reverse the conclusions suggested by short-term trends.

One way to avoid the short-term focus that occurs with annual deficit statistics is to explicitly project the present discounted value of future outlays 
that are implied by currently-legislated programs, to add this to the value of outstanding debt, and to compare this with the value of salable government assets. This is essentially the procedure that underlies the projection component of the "generational accounts" algorithms that have been developed by Auerbach, Gokhale, and Kotlikoff (1991). These algorithms use available information on projected economic and demographic conditions to evaluate the long-term evolution of government spending. While the precise assumptions underlying any set of generational accounts may be open to question, the general finding that these accounts provide additional insight on the budget process is difficult to refute.

\subsection{The Balanced Budget Amendment \& Gramm-Rudman-Hollings}

The shift from near balance in fiscal policy to persistent peace-time federal deficits starting in the mid-1970s led to emerging policy concern about fiscal policy. This concern first reached a critical juncture in August 1982, when the Senate passed a Balanced Budget Amendment (BBA) by a 69-31 margin, two more than the two-thirds majority needed for a constitutional amendment. The proposed amendment required Congress to adopt a balanced budget before the start of each fiscal year, although it incorporated limited override provisions for deficits in wartime or if approved by $60 \%$ of Congress. Despite support from the White House, the BBA did not pass the House of 
Representatives by the required two-thirds majority.

Even though the BBA could not command sufficient legislative support for passage, it indicated a desire to alter the budget process in ways that would reduce the chance of future deficits. As chronicled in Poterba (1994a), these desires surfaced again in late 1985 , when the Senate took up legislation to raise the federal debt limit from $\$ 1.8$ trillion to $\$ 2.1$ trillion. The expansion in debt authority was needed to avoid a federal financial crisis, since increased borrowing was required to make federal interest payments. During the debate on the debt ceiling bill, Senators Phil Gramm, Ernest Hollings, and Warren Rudman took the initiative on broad deficit issues and introduced a bill requiring a phased-in program of deficit reduction, leading to budget balance in fiscal 1991.

The Gramm-Rudman-Hollings (GRH) bill that passed the Senate by a wide majority had two components. The first altered the timing of the federal budget process, accelerating budget discussions and placing deadlines earlier in the calendar year in an effort to permit more deliberation before the start of the fiscal year. The second objective was to introduce a set of deficit targets and a mechanism for ensuring that actual deficits did not exceed them. The key provisions were:

(i) the president would be required to submit budgets with forecast deficits no greater than the target for a given year; 
(ii) OMB and CBO would prepare estimates of the projected deficit from the enacted budget and tax legislation;

(iii) if the average of the $\mathrm{CBO}$ and $\mathrm{OMB}$ deficit computations exceeded the target, then the President would have two weeks to issue a sequester order, requiring permanent reductions in budget authority for all outlays other than a set of exempt programs, which included means-tested entitlement programs, interest on the federal debt, government pensions, and existing contractual obligations;

(iv) half of the sequester cuts would come from entitlement programs with automatic spending increases, such as Medicaid, AFDC, and Food Stamps, while the other half would come from other discretionary programs; and

(v) a suspension clause rendered the need for spending cuts inoperative if the economy was in recession. This would occur if actual economic growth fell below one percent for two consecutive quarters, or if the $\mathrm{CBO}$ or $\mathrm{OMB}$ projected negative growth for two quarters. The suspension clause would also apply in periods when there was a war declared by Congress, or whenever a three-fifths majority of Congress voted for such suspension.

The Gramm-Rudman-Hollings bill represented a substantial change in the rules governing budgetary politics in the United States. The conference bill that was signed by President Reagan called for a deficit target of $\$ 171.9$ billion in fiscal 1986 , declining to zero by fiscal 1991 . Half of the automatic cuts would 
come from defense and half from non-exempt non-military programs, including AFDC, Medicaid, and Social Security. All programs would have to be cut proportionally, thereby limiting Presidential discretion. A key provision required the General Accounting Office (GAO) to calculate the average of the OMB and CBO deficit estimates and transmit an estimate of the needed sequester to the President. AFDC, Medicaid, and Social Security were excluded from the sequestration process.

The GAO provision was the basis for a constitutional challenge to GRH. In July 1986, the Supreme Court declared GRH unconstitutional, on the grounds that because Congress can dismiss the head of the GAO, the bill provided executive authority to an organization which was under legislative control. The Supreme Court decision derailed the first Gramm-Rudman-Hollings deficit limitation plan. A year later, the Senate passed new legislation, sponsored by Senators Gramm, Chiles, and Domenici, in which the final step in the sequester process required GAO to submit its report to $O M B$, an executive agency. OMB would review the GAO report, and the president would then issue an order based on it to enforce spending cuts. The deficit targets were loosened from levels in the previous year's legislation to require a deficit of $\$ 144$ billion in fiscal 1988 , declining to zero in fiscal 1993 . In addition, the law permitted a $\$ 10$ billion margin of error in all years until 1993. President Reagan signed this bill in September, 1987. Although it was technically 
different from the original Gramm-Rudman-Hollings bill, this legislation is frequently referred to as Gramm-Rudman or Gramm-Rudman-Hollings, and it shall be referred to as GRH in what follows.

\subsection{Deficit Experience Under Gramm-Rudman-Hollings}

When GRH was enacted, many analysts predicted that it would have no effect on tax and spending outcomes, because Congress and the President could always agree to modify the targets. Others noted that it would be straightforward to circumvent the budget targets with a series of budgeting gimmicks, such as the postponement of some expenditures until the first day of the next fiscal year or the acceleration of some receipts. Both of these concerns proved correct to some degree, but at least some studies conclude that in spite of these issues, GRH did affect budgetary outcomes.

The initial experience with GRH supported those who doubted that it would matter. In 1987, when Congressional leaders concluded that the fiscal 1988 deficit target specified by GRH was unattainable, the timetable for deficit elimination was extended and the near term deficit targets were increased. A similar strategy was invoked in 1988. Much of the budget "savings" in these years was achieved through a variety of accounting manipulations and one-time revenue raisers, including asset sales and moving some agencies, such as the postal service, off-budget. These factors, coupled with other shocks such as 
rapid growth of medical care costs during the late 1980 s and the expenses associated with the savings and loan bailout, led to deficits substantially above the initial GRH targets. This failure to achieve the hoped-for deficit reduction led to further budgetary reform in the 1990 Budget Enforcement Act. Yet it may be inappropriate to dismiss GRH as ineffectual simply because substantial deficits remained at the end of the 1980s.

Gramlich (1990), Hahm et al. (1992), and Reischauer (1990) present careful analyses of deficit reduction and GRH. Two of these studies were prepared by participants in the budget process. Gramlich begins by observing the decline in average federal deficits between the years immediately before, and the years after, the enactment of GRH. He cautions that while this pattern provides superficial support for the effectiveness of the deficit legislation, the disaggregate pattern of spending and revenues suggests that not all of the deficit reduction could be attributed to anti-deficit legislation. He calculates that there was a $2.8 \%$ of GDP decline in the primary deficit between the 19831986 period and 1989 , and he attributes this change among various factors as follows:

\begin{tabular}{ll} 
Nondefense Baseline Drift & $1.2 \%$ \\
Defense Base Calculation & 0.8 \\
Higher Taxes & \multicolumn{1}{c}{1.0} \\
Other Factors & -0.2 \\
Total & $2.8 \%$
\end{tabular}

The single most important factor in deficit reduction, nondefense baseline 
drift, reflects the declining GDP share of entitlement programs as productivity and other factors lead to increases in real GDP. The next largest component, the increase in taxes, was due in roughly equal parts to the increase in payroll taxes in the 1983 Social Security compromise, and to the increase in corporate taxes under the Tax Reform Act of 1986. The latter could have been affected by the GRH budget rules, since some of the provisions, such as less generous depreciation schedules for some assets, would raise revenue in the short term, but reduce revenue in the longer term.

The changing defense baseline spending was proximately the result of GRH, which replaced the previous practice of projecting the growth rate of defense outlays on the basis of some earlier budget agreement with the practice of projecting current real level of outlays into the future. This change, adopted as part of the sequester procedure in GRH, had the effect of reducing the projected level of defense outlays, and thus the base from which contributions to the deficit were assessed. But Gramlich (1990) argues that the change in defense projections probably reflected changing political support for defense spending, rather than a revision in the principles of budgeting. After dissecting the budget components, Gramlich (1990, p. 80) concludes: "the fact that GRH was instituted just as primary deficits were dropping seems largely coincidental ... changes in the process due to GRH seemed to have little to do with the improvement." 
Hahm et al. (1992) reach a somewhat different conclusion. They present the most disaggregate analysis of how GRH affected the outcome of the budget process. They rely on a multi-sector model of federal spending, which relates spending on each of sixty sub-categories of federal spending to a set of variables that are plausibly related to spending choices, such as the fraction of households in poverty and the presence or absence of a war. They use their model to simulate spending in the late 1980 s in the absence of $\mathrm{GRH}$, and compare the findings with the actual spending levels that were observed during this period. They conclude that there was no systematic change in spending levels for programs that were exempt from sequestration, but that spending for programs subject to sequestration did decline after GRH was enacted. Their central estimates suggest that GRH reduced spending on these programs by nearly $\$ 60$ billion in fiscal 1989.

Whether Gramlich's (1990) investigation or Hahm et al.'s (1992) analysis represents a better assessment of the impact of GRH is unclear. The difficulty of performing the counter-factual experiment of observing spending in the absence of GRH makes it difficult to evaluate observed budget outcomes, and the lessons from the GRH experience may simply be too subtle to interpret with confidence.

Reischauer (1990) provides evidence on the importance of several budgetary "gimmicks" that were used to reduce measured deficits. First, he 
notes that the Congressional Budget Office estimates that approximately half of the deficit reduction during the GRH period was achieved through one-shot fiscal measures, such as asset sales. While this suggests that concerns about budget manipulation are not without basis, it also suggests that approximately half of the deficit reduction was not due to these factors. Second, Reischauer (1990) presents evidence on the increasingly optimistic economic assumptions that were used by OMB in projecting future deficits. Table 2 shows the time profile of CBO's economic and technical adjustments to the President's budget for each fiscal year from 1983 to 1991 . The average correction rises from $\$ 8$ billion in the four years before GRH took effect to $\$ 36$ billion in the six years afterward. This pattern, confirmed by Auerbach's (1994) evidence on various sources of revision to budget estimates, suggests that one of the important consequences of GRH was to place greater pressure on forecasters to use optimistic assumptions that would make deficit reduction easier.

This example of endogenous forecast optimism illustrates the difficulty of controlling budget outcomes on any multi-year basis. It is almost always possible to predict a balanced budget over some horizon, if the budget forecaster has enough discretion in setting the underlying economic assumptions. Because GRH did not place restrictions on this aspect of the budget process, some of the deficit reduction that was generated by GRH was the result of adjustment along this margin. 


\subsection{The Budget Enforcement Act of 1990}

The inability to achieve the GRH deficit targets led to renewed discussion of deficit reduction only three years after the GRH was enacted. The result was the 1990 Budget Enforcement Act, which added two new features to budgeting procedures. The first is a series of annual caps on discretionary spending, which require real reductions in outlays on these programs. The second is a pay-as-you-go (PAYGO) rule for entitlement spending excluding Social Security.

This requires a non-negative net revenue effect in each fiscal year of all mandatory and revenue legislation approved since the 1990 Budget Act. This had the effect of requiring any proponent of a policy that would increase spending on one program to also propose cuts in another program, or a specific mechanism for raising revenues. Social Security, while excluded from the overall entitlement program pay-as-you-go rules, is subject to a separate but similar set of rules. The 1990 BEA applied to fiscal years from 1990 to 1995 , but the central provisions have been extended through fiscal 1998 by the Omnibus Budget Reconciliation Act of 1993.

The 1990 BEA differs from GRH in a critical respect. While GRH specified numerical deficit targets on a year-by-year basis, the BEA specifies only that enacted policies cannot raise deficits relative to initial projected levels. Thus, if existing programs expand prospectively, or existing revenue sources contract, or economic conditions are such that deficits are projected to grow, the BEA 
would not limit these deficits in any way. BEA is thus an example of a reform in budget process, while GRH was in large part a stipulation of budget targets.

Auerbach (1994) formalizes this important difference between GRH and the 1990 BEA. He notes that under GRH if the deficit target for year $t$ had been set at $D_{1}^{*}$, and the deficit projection at the end of the previous fiscal year was ${ }_{t-1} D_{t}$ then the deficit consequences of policy changes in year $t\left(P_{t}\right)$ are constrained by the rule:

$$
P_{t}<D_{t}^{*}-{ }_{t-1} D_{t}
$$

This implies that the actual deficit for fiscal year $t$ will deviate from the deficit target only by the amount of "technical projection errors" for the fiscal year.

Under the 1990 BEA, policies cannot be predicted to raise the deficit in any of the next five fiscal years. In this case, Auerbach (1994) shows that the realized deficit in year $t$ will equal the projected deficit in that year from five fiscal years earlier, plus any revisions in the deficit projection that are due to economic or technical errors in the ensuing five years.

The BEA rules create strong incentives for enacting policies that will not affect deficits during the next five fiscal years, or whatever the budget window is, but will expand deficits further in the future. For example, a bill that promised to eliminate the federal income tax and balloon the deficit in six years would not be identified as deficit-enhancing by the BEA, since its deficit expansion would occur outside the BEA window. Such a policy would show 
up as a large projected baseline deficit in fiscal year $t+6$. All BEA requires is that policies enacted in the next five years would not increase that projected deficit relative to what it was when first forecast.

Auerbach (1994) presents evidence that the shifting budget process of the last decade has led to changes in the relative importance of various factors that contribute to deficits. In particular, he shows that between 1987 and 1990, there was some tendency to reduce deficits in the current fiscal year at the expense of deficits in near-term future years. Because the 1990 BEA restricted the possibility of raising deficits in the next five years to reduce current fiscal year deficits, it has led to less near-term deficit retiming, but potentially more long-term retiming. A key factor behind the slow decline in federal budget deficits appears to be a continuing flow of "forecast errors" that have raised deficits relative to previous expectations. These errors can be due to changes in policy, changes in economic assumptions, or technical factors, and the relative importance of different types of errors seems to have been affected by changes in budgetary rules.

The enactment of the 1990 BEA coincided with the acceleration of a long-standing trend in the composition of federal outlays. Tables 3 and 4 present information on federal spending by BEA category, discretionary vs. nondiscretionary, for the period 1965 through 1998 (projected). The tables show a sharp decline in discretionary spending as a share of GDP, from $9.2 \%$ in 1990 
to a projected $6.6 \%$ in 1998 . This decline is nearly as large as the drop between 1970 and $1990(12.6 \%$ to $9.2 \%)$, and is primarily the result of a projected decline in defense outlays. The GDP share devoted to mandatory programs is projected to increase during the 1990 s, from $10.3 \%$ in 1990 to $11.2 \%$ in 1998 . This increase is largely the result of a growing GDP share allocated to means-tested entitlement programs, which include Medicaid, Food Stamps, AFDC, SSI, child nutrition programs, veterans pensions, and the Earned Income Tax Credit. Spending on these means-tested entitlements equalled $1.7 \%$ of GDP in 1990, and had increased very little in the previous fifteen years. It is projected to rise to $2.8 \%$ of GDP by 1998 .

The changing GDP shares accounted for by different types of spending can be placed in stark relief by calculation the shares of the federal budget accounted for by various expenditure items. Discretionary spending, which was more than half of the federal budget as recently as 1974 , declines from $40.1 \%$ in 1990 to $31.0 \%$ in 1998 . Mandatory spending rises from $45.2 \%(1990)$ to $52.8 \%(1998)$, while net interest increases by $1.5 \%$ of the total budget. These statistics suggest that the share of the federal budget that is directly controllable by changes in current program outlays, without manipulation of entitlement rules, is small and declining. The open question is whether the trend toward reduced discretionary spending was accelerated by the spending caps in the 1990 Budget Enforcement Act; anecdotal evidence suggests that 
this may be the case.

\subsection{If Anti-Deficit Rules Work. Why Do They Work?}

Although the experience with GRH is difficult to interpret, evidence on the shifting composition of federal spending since the passage of BEA 1990, and Auerbach's (1994) findings on the changes in the source of "errors" in the budget process, suggest that changes in the budget process during the last decade have coincided with changes in fiscal policy outcomes. The fundamental difficulty in evaluating anti-deficit rules is the institutional endogeneity problem described above. The passage of GRH and later BEA may signal shifting voter preferences, as reflected in the political process, for high deficits, tax reductions, and spending increases. If so, then the budget outcomes observed since the enactment of these reforms may not be due to these laws per se, but may reflect changing fiscal tastes more generally. It may be impossible to reject this view given the short data samples since the passage of these laws.

If one were to subscribe to the view that these institutional changes affected policy outcomes, however, what would the mechanism for such effects be? There are two channels through which deficit targets like those in GRH and BEA may affect fiscal policy. First, they provide a benchmark for budget deliberations, an objective standard against which the President's 
budget proposal or Congressional modifications can be evaluated. Media discussions of whether particular proposals meet the deficit targets appear to "score" different proposals, and may encourage frugality by both the President and the legislature. Gramlich (1990) argues that even though his statistical analysis does not suggest a large direct effect of GRH, it may still be possible that GRH changed the terms of budget policy debate. In particular, GRH introduced the notion of "revenue neutral" and "deficit neutral" policies, thereby setting the ground rules for many of the tax and spending policy debates of the late 1980 s and early 1990 s. Provided it is not costless to manipulate reported budget numbers, policies that attach costs to failure to report particular deficit values will have real effects.

Second, in the case of GRH, the sequestration procedures through which cutbacks occur enable current legislators to shirk some responsibility for spending reductions, blaming the cuts on the Congress that enacted the budget targets. While Congress and the President may opt to circumvent this process if the cuts are too painful, a sequester that is perceived as an equitable reduction in expenditures might be allowed to take effect. In any case, the threat of a painful sequester probably does provide some pressure for budget compromise. Developing theoretical models in the spirit of positive political economy that explain how power is allocated in budgetary deliberations is an important future research issue. 


\section{The Effect of Budget Institutions: U.S. State Evidence}

While the federal budget policy reforms of the last decade provide a potentially valuable source of information on how budget rules affect policy outcomes, as the foregoing discussion suggests, it can be difficult to evaluate the evidence from a single episode of policy reform. To expand the base of variation in budget rules available for study, it is therefore helpful to consider information from other jurisdictions or time periods. Data from the U.S. states provides one promising source of evidence on the impact of budget rules.

This section, which draws on Poterba (1995a), focuses on state balanced budget rules, most of which are substantially different from those currently being discussed at the federal level. In particular, virtually all states allow some types of borrowing to be used in budget balancing, most states apply the balanced-budget rule to only part of their budget, and there are virtually no formal provisions for enforcing state balanced-budget rules. Thus the states do not provide evidence on whether sequesters or other devices are particularly effective in reducing budget deficits. These limitations notwithstanding, evidence on the effects of state balanced budget institutions is relevant for the broader question of whether fiscal institutions can affect fiscal policy outcomes.

\subsection{State Balanced Budget Rules}

Most state constitutions preclude deficits in state operating budgets, but 
the nature and scope of these limits varies widely. Detailed summaries of state budget practices may be found in National Association of State Budget Officers (1992) and the U.S. General Accounting Office (1993). Only one state, Vermont, does not have a balanced budget requirement. The balanced budget requirements in the forty-nine states with such requirements can be broadly categorized into three groups, depending on the stage in the budget process at which balance is required.

First, in forty-four states, the governor must submit a balanced budget. This is the weakest of the various balanced budget requirements. Second, thirty-seven states impose a stricter standard, requiring that the legislature enact a balanced budget. These balanced budget rules nevertheless allow for actual revenues and expenditures to diverge from balance if realizations differ from expectations. In many states that require passage of a balanced budget, the actual budget may be in deficit, and the state can borrow to carry this deficit forward to future years.

The third and strictest type of balanced budget rule combines a requirement that the legislature enact a balanced budget with a prohibition on deficit carry-forward. This is the situation in 24 of the $\mathbf{3 7}$ states that require the legislature to enact a balanced budget. Such stringent anti-deficit rules are more common in small than large states; seven of the ten largest states allow deficits to be carried forward to subsequent years. 
An important difference between existing state balanced budget rules and recent proposals at the federal level is that state rules frequently apply to only part of the budget. The general fund, or state operating budget, is almost always subject to a balanced budget rule. In $\mathbf{4 8}$ of the $\mathbf{4 9}$ states classified by NASBO (1992) as having balanced budget rules, these rules apply to the general fund. Such rules are less likely to apply to special funds (34 states), such as those with earmarked tax receipts or used to fund particular programs such as intergovernmental aid, capital spending funds (33 states), and trust funds (30 states) such as those for highways or some social insurance programs. In some cases, particularly with respect to the capital account, funds raised by issuing long-term debt can be included in the revenue flow that balances the budget.

There is substantial variation across states in the fraction of state spending that is likely to be affected by balanced budget rules. In the NASBO (1992) survey, three states reported that between 25 and 50 percent of their spending was affected by these rules, nine states reported that $50-75$ percent of spending was affected, and the remaining states with balanced budget rules indicated that these rules applied to at least 75 percent of their state spending.

States that face budget deficits at some stage of their budget process have three options for closing such deficits. They can raise taxes, reduce spending, or change "budget execution" to close the apparent deficit. Some 
actions that fall in the latter category might be labelled "cosmetic" budgetary changes, such as deferring payments across fiscal year, or accelerating receipts. The General Accounting Office's (1985) study provides several examples of the changes that were used to satisfy budgetary targets in the early 1980s. California transferred revenues from an oil extraction royalty tax from a trust fund to the general fund; New York enacted a new payroll system to shift its last payroll payment from fiscal year 1983 into the next fiscal year; Minnesota accelerated tax collections to move receipts across fiscal years. The state experience suggests that while some cosmetic changes are used to meet balanced budget requirements, these changes are quantitatively less important than tax increases and spending cuts.

The GAO's (1993) survey of state budgeting collected information on the dollar value of various accounting changes that states used to meet balanced budget targets. Twenty-five states reported that they had faced prospective deficits during a recent budget enactment period, and taken actions to close these deficits. Nearly half (49 percent) of the deficit reduction was achieved through spending cuts, another 32 percent through revenue increases, and the remaining 19 percent through "other actions" such as accounting changes. In addition, 32 states reported that they had faced prospective deficits after budget enactment, and taken actions to close these deficits. Spending cuts accounted for 60 percent of the within-fiscal-year deficit reduction, revenue 
increases 4 percent, and "other actions" accounted for 36 percent. These "other actions" included drawing down rainy day funds (32 percent of the total deficit reduction), interfund transfers (22 percent), short term borrowing (17 percent), deferred payments (13 percent), as well as a number of other changes in budget execution. Accounting changes and related actions thus appear to account for a substantial part of fiscal adjustment within the budget cycle, but they are not the primary source of longer-term state deficit reduction.

The GAO (1993) findings provide important support for the possibility that changing the definition of the budget deficit would affect real fiscal outcomes, at least when there are anti-deficit rules in place. They suggest that states take actions to achieve a balanced budget, even in the absence of stringent enforcement provisions. Gold (1992) notes that most states have no formal enforcement mechanisms for their balanced budget requirements, and the GAO (1993) reports that there have never been lawsuits to challenge state budgeting outcomes, even though there have been instances when budgets failed to balance. According to the GAO's (1985) survey, state policy-makers appear to view tradition, or a history of balanced budgets, as the primary factor encouraging them to maintain budget balance. It is not clear how such experience can be translated to analyze the potential effects of federal antideficit rules. 


\subsection{Balanced Budget Rules. Taxation, and Expenditures}

A number of research studies have considered the effects of balanced budget rules on the size and persistence of state budget deficits, and on state tax and expenditure levels more generally. There is a substantial literature, exemplified by Preston and Ichniowski (1991) and Dye and McGuire (1995), suggesting that local property tax limitation laws have important effects on the level of local taxes. The evidence on state-level budget institutions is more limited.

Evidence from simple cross-sectional comparisons of state institutions and spending levels provides inconclusive evidence on the impact of such institutions on fiscal outcomes. Abrams and Dougan (1986) conclude that such limits do not have substantial effects. Other studies, such as Eichengreen's (1992) analysis of the effect of limits on state debt and spending, and Crain and Miller's (1990) study of how such limits affect spending growth rates rather than levels, do report that tax limits constrain government size or growth.

Two recent studies represent important advances in the analysis of tax and expenditure limits. Shadbegian (1996) estimates regression models for both the level and the growth rate of state government spending, as a function of both the presence of tax and expenditure limits, and the interaction between these limits and the state's personal income growth rate. He finds that the 
interaction effect is particularly important, because many tax and expenditure limits are specified as a limit on state spending as a fraction of personal income. In states with slow income growth rates, limitation laws have had a more restrictive effect on government growth than in fast-growth states.

A second recent study, Rueben (1995), presents the most careful control to date for the endogeneity of fiscal institutions, and therefore generates the most compelling evidence on how these institutions affect policy outcomes. Rueben (1995) uses both historical variation in state institutions as well as differences in the political process that may facilitate the passage of tax limits to model and attempt to correct for the endogeneity of budget rules. Her empirical findings show that while ordinary least squares regressions of spending levels on fiscal institutions lead to statistically insignificant findings, after the presence of these institutions is treated as endogenous, the explanatory power of the institutional variables rises markedly, and the estimated effects become negative.

In addition to the substantial body of research on the impact of tax and expenditure limits on state or state and local government spending, several studies have considered the effect of anti-deficit rules, possibly in conjunction with limits on borrowing or other fiscal limits. Three recent empirical studies provide important support for the real effects associated with fiscal rules.

Alt and Lowry (1994) analyze data from the Census of Governments for 
the period 1968-1987. They model state revenue and expenditures as a function of current state income, current federal grants, lagged values of state revenue, state expenditures, the lagged difference between revenues and expenditures, and a set of indicator variables for state political circumstances. They compare fiscal policy reactions to disparities between revenues and expenditures, which can exist even in states with balanced budget requirements. They find that a one dollar state "deficit" in the current year triggers a 77 cent response, through tax increase or spending reduction, for states that are Republican-controlled and prohibit deficit carryovers, compared with a $\mathbf{3 4}$ cent reaction in states that are Democrat-controlled and have such limits. In states that do not restrict deficit carryovers, the adjustments are 31 cents and 40 cents respectively for Republican and Democratic states. This empirical evidence suggests that state politics is an important influence on deficit reduction, and that at least some political configurations, variation in anti-deficit rules is associated with variation in fiscal actions.

Bohn and Inman (1995) explore the effect of fiscal institutions in a panel data set that includes information on forty-seven states for twenty-two years. They find that balanced budget rules that restrict end-of-year budget deficits have a statistically significant effect in reducing state general fund deficits, with an average deficit-reducing effect of approximately $\$ 100$ per capita. "Soft" constraints on proposed budgets do not affect deficits. The deficit reduction 
in states with tight anti-deficit rules appears to result from lower levels of spending, not higher taxes, in these states.

Poterba (1994b) presents evidence on how state balanced budget rules affect the way state fiscal policies respond to unexpected deficits or surpluses. This study considers both within fiscal year adjustment, through spending cuts or tax increases, as well as adjustment in the next fiscal year. It focuses on how an indicator variable for states with "weak anti-deficit rules," as classified in the Advisory Council on Intergovernmental Relations (1987) study on fiscal stringency, is related to state reactions to fiscal shocks. The results, which are based on the twenty-seven continental states with annual budget cycles, suggest that states with weak anti-deficit rules adjust spending less in response to unexpected deficits than do their counterparts with strict anti-deficit rules. A 100 dollar deficit overrun leads to only a 17 dollar expenditure cut in a state with a weak anti-deficit law, while it leads to a 44 dollar cut in other states. There is no evidence that anti-deficit rules affect the magnitude of tax changes in the aftermath of an unexpected deficit.

The cumulative evidence from these three studies, using different time periods and data samples, suggests that budget rules do affect deficit policies. These studies do not provide much guidance on the long-term issue of whether tighter anti-deficit rules reduce spending or taxes, but rather emphasize the high-frequency effect of fiscal institutions on the conduct of fiscal policy. 


\subsection{Balanced Budget Rules and State Borrowing}

In addition to the evidence on how balanced budget rules affect tax and spending policies, there is also some evidence on how these rules, and related debt limitation laws, affect the level of state indebtedness. von Hagen (1991) compares the level of state general obligation debt, per capita and relative to state income, in states with and without stringent balanced budget requirements. His findings suggest that general obligation indebtedness is substantially lower in states with stringent balanced budget amendments than in other states. He also explores the effect of stringent balanced-budget rules on the ratio of non-full faith and credit to full faith and credit debt across states. States with more stringent deficit limits, as well as states with lower general obligation debt limits, exhibit higher levels of revenue debt and other debt that is not backed by the full faith and credit of the state. These results are consistent with Bunch's (1991) demonstration that states with tighter debt limits or balanced budget rules are more likely to use public authorities and other alternatives to state-backed borrowing to finance various projects.

Kiewiet and Szakaly (1996) present a related analysis of the real effects of anti-deficit rules and related limits on state borrowing. They study whether state constitutional debt limits have any effect on total state indebtedness, or on the composition of this debt. The only institution that the authors find to be highly negatively correlated with state indebtedness is a requirement that 
state debt be approved by popular referendum. This suggests that a combination of a stringent anti-deficit rule and a requirement that debt be approved by the voters is likely to bring pressure for tax increases or spending cuts, rather than debt finance, in response to state deficits. This evidence is also consistent with the findings reported above on the effect of tax limitation laws. Constitutional or legislative provisions that make it more costly to balance the budget in a given fashion, by raising taxes or by issuing long-term debt, appear to have real effects in discouraging these fiscal actions.

Most research on the real effects of budget rules has focused on how these rules affect deficits or the level of taxation and spending. An intriguing alternative perspective on these rules is developed in developed in Goldstein and Woglom (1992), Bayoumi and Woglom (1995), and Lowry and Alt (1995). These studies focus on the interest rates at which states can borrow funds, and how these borrowing rates are related to fiscal rules. Goldstein and Woglom (1992) relate the interest rate on general obligation debt to the ACIR index of state limits on deficits described above. Their results, which also control for the level of state indebtedness and the observed state deficit, suggest that a state with the most restrictive set of fiscal limits faces an interest rate .05 percentage points lower than a state with an average set of limits.

Lowry and Alt (1995) show that the bond market reaction to a state deficit projection depends on whether the state has a balanced budget 
requirement. States with balanced budget rules experience smaller increases in their borrowing costs for a given deficit. These results are a first step toward a normative analysis of whether states benefit from adopting anti-deficit rules. They are important in the current context because they suggest that capital market participants, who have strong incentives to monitor and evaluate state fiscal performance, consider the presence of anti-deficit rules in evaluating state fiscal conditions.

These findings on budget rules and borrowing behavior provide important confirmation for the earlier results on how budget rules affect reported deficits.

The substantial empirical literature on state budgeting and fiscal policy provides clear support for the view that budget rules matter, and that changing the rules that govern the taxation and expenditure process can alter the outcomes of this process.

\subsection{What Can Be Learned From State Experience?}

One key question that arises in evaluating the state experience with antideficit rules and tax limitation laws concerns the difference in fiscal equilibrium processes between states and national governments. Voters can move between states and other sub-federal jurisdictions; this may limit the fiscal behavior of states, but not national governments. Consider, for example, the consequences of a state choosing to transfer funds from its pension account 
to the current account, thereby balancing the current budget at the expense of future fiscal balance. If residents and potential residents recognize the future tax liability associated with such a transaction, and if future taxes are lump-sum levies on landowners, then the price of land in the state should decline to exactly offset the future tax burden. Such capitalization effects are not likely to operate at the federal level.

There are also important differences in the constraints that ultimately affect state and federal policy makers in the United States. Because the federal government can resort to printing money as a means of financing a deficit, while states cannot, states may face tighter limits on fiscal actions. States may also differ from the federal government in their degree of access to credit markets. As the New York City fiscal crisis of 1975, and some of Philadelphia's fiscal difficulties of the early 1990s, demonstrate, it is possible for sub-federal borrowers to simply be denied access to credit. Such credit market factors may discipline state policy makers but not impose the same restraints on federal decision-makers.

Another potential difference between states and the federal government concerns information. In Washington, numerous watchdog groups provided commentary and analysis on budget proposals and outcomes, often drawing on quite sophisticated analytical frameworks. There is less external oversight in many state capitals. The role of the federal budget document in describing 
federal fiscal policy may therefore be less central than the analogous role of budget documents in the states. Whether this limits the application of statelevel findings in federal policy discussions is an open issue.

\section{The Effect of Budget Institutions: International Evidence}

Cross-sectional comparisons of state budget outcomes and budget rules is one way of exploiting jurisdictional variation in budget institutions; international comparisons of the same type represent another research opportunity. A number of studies have pursued this research direction, and found effects of fiscal institutions as well as related variables that describe political circumstances. While this research is more likely than cross-state analysis to be affected by omitted variables that are correlated with both fiscal tastes and budget institutions, it is nevertheless valuable to summarize the primary findings.

Before considering international comparative evidence, it is important to recognize that the differences in budget processes across countries are much greater than the differences between states within the United States, or than between the differences between the U.S. in 1984 and 1988. It is therefore necessary to develop a typology for categorizing budget rules. The two aspects of budget process that have proved most important in previous analyses are the degree of centralization or authority in the budget process, and the degree of 
budget "transparency." With respect to centralization, at one extreme are authoritarian institutions, which centralize power in the hands of a treasury minister or another small group of decision makers. At the other extreme are collegial institutions, which disperse power and require substantial consensus at one or several stages of the budget enactment process. Alesina and Perotti (1995) discuss institutions along this spectrum, and von Hagen (1992) provides summary information on the budget process in European Community nations. Budget transparency is more difficult to categorize.

With respect to transparency, there are important differences in the way budgets are prepared, debated, and ultimately approved by the legislature. Von Hagen (1992) interviewed policy-makers who are involved in the budget process in a range of European nations, and he constructed indices of transparency based on the number and significance of "special accounts" in the budget, whether or not all budget information was presented in a single document, and related measures. On the basis of these responses and other information on the nature of the budget process, he constructs indices of government budget rules. The OECD (1995) provides a more recent survey of detailed budgetary practices in a sample of developed nations, but this report does not distill the information to summary statistics that can be used for standardized international comparisons.

Von Hagen's (1992) indices of budget stringency are extremely valuable 
for studying international differences in budget outcomes, but they must be viewed with some caution. Essentially, these indices are constructed by adding together a set of categorical variables. This implicitly assumes that various indicators for the restrictiveness of the budget process operate as perfect substitutes. A country with a weak prime minister, hence a low score on one dimension of budget practice, can nevertheless achieve the same score on the budget process index as another nation with a strong prime minister if the weak-minister nation has fewer special accounts in the budget process. Ideally one would like to distinguish separate effects for various budget rules, but this may be impossible in analysis of data from a small set of countries with little intertemporal variation in budget rules.

Von Hagen and Harden (1995) use these indices of budget process to estimate simple cross-sectional regression models relating budget structure to fiscal outcomes such as the debt/GDP and deficit/GDP ratio. The results suggest that tighter budget rules are associated with lower budget deficits and reduced levels of government borrowing. The authors also note some regularities about the countries that have modified their budget process in an effort to reduce fiscal deficits. Procedural reforms, as opposed to budget target reforms, have succeeded in all of the large EU nations that have successfully reduced budget deficits in recent years (France, Britain, and Germany). This finding bolsters the tentative U.S. evidence suggesting that the Budget 
Enforcement Act of 1990 may have a greater effect on fiscal policy outcomes than GRH did.

Subsequent studies have confirmed the presence of fiscal effects correlated with budget structure. Alesina and Perotti (1995b) present related empirical work. They find that coalition governments are much less likely to pursue tight fiscal policies, or successful "fiscal adjustments," than are singleparty governments. This evidence supports the key role of a strong decision making in promoting fiscal restraint, and may be extrapolated to suggest that strengthening the role of a central player in any budget negotiation can impose discipline on the fiscal policy process.

One of the most intriguing empirical studies to date is Alesina, Hausmann, Hommes, and Stein's (1995) analysis of budget rules and fiscal outcomes in a sample of Latin American economies. This study develops separate indices for the presence of constitutional constraints on borrowing, for the importance of the Finance Minister or other key participant in the budget process, and for the relative power of the legislature and the executive in budget deliberations. The empirical results suggest that stronger Finance Ministers are systematically correlated with smaller primary deficits. This research also suggests an important effect for the relative power of the legislature and the executive; a more powerful executive leads to smaller primary deficits.

None of the foregoing studies address the problem of institutional 
endogeneity, which raises some questions about the interpretation of their findings. One important subject for future analysis should be the careful modelling of the origin of budget institutions in an international context.

\section{Conclusions}

This paper summarizes what we know about a range of issues that involve budget institutions and fiscal policy outcomes. What conclusions, if any, can we draw from the existing literature? First, fiscal institutions do matter. Although the evidence is not conclusive, the preponderance of studies suggest that institutions are not simply veils that are pierced by voters, but are important constraints on the nature of political bargaining. Studies of the demand for public spending, whether by state and local governments or by nations, should recognize that this demand is mediated through a set of fiscal and budgeting rules. The evidence from empirical studies of fiscal institutions and budget outcomes suggests that tightly-drawn anti-deficit rules, especially when coupled with limits on government borrowing, induce smaller deficits and more rapid adjustment of taxes and spending to unexpected fiscal shortfalls. It is not unreasonable to interpret this evidence as suggesting that modifying the federal budget process could affect federal fiscal policy.

Yet in spite of this emerging body of empirical evidence, much remains to be learned about budget processes and budget outcomes. There are two 
central issues that have not yet been resolved, and require further research attention. First, there is no agreement on the underlying politico-economic model that should be used to predict the effect of changes in fiscal institutions. There are both basic and applied issues unresolved in this vein. For example, to what degree are legislative bodies organized to facilitate log-rolling and other types of coalition formation? How should one model the conflict between an executive with ostensible commitment to the interests of the nation, with district-based legislators whose interests lead them to support projects that benefit their districts? How important are information flows between various actors in the budget process, and is information or the power to threaten painful cuts in programs the more important mechanism for changing the budget process?

Political scientists and economists have proposed various models of how legislative bodies such as the Congress operate, for example Weingast and Marshall (1988), but the models have not yet reached a degree of sophistication that permits strong answers to detailed questions. Budget rules that restrict the discretion of budget actors, either by constraint current actors to achieve budget targets that were enacted in the past, or by limiting the ability of individual committees within congress to control their appropriations, entail a trade-off. They may promote desirable aggregate budget objectives, but do so at the cost of reducing the amount of information that can be brought 
to bear on particular budget decisions. Models of information flows in legislatures, and the effects of changing such flows, therefore seem potentially relevant in assessing fiscal limit laws.

While empirical research has explored the correlations between some rather specific aspects of budget policy and observed spending outcomes, with examples being Holtz-Eakin's (1988) study of state line item veto provisions or my own (1995b) study of capital budgeting rules, there is little theory to guide the empirical researcher in choosing covariates or control variables in such models. Given the tremendous interest in political economy models and deficit issues in the last decade, however, and the progress during this period, it is not unrealistic to expect future progress on this front.

Second, the existing body of empirical research has not been very successful at disentangling the components of various budget policies. For example, is the sequester provision or the change in the timing of the budget functions more important in the 1986 Gramm-Rudman-Hollings legislation? Which feature of the various budget institutions that are considered in crosscountry studies like von Hagen's (1992) analysis are the most important for influencing fiscal policy? This is a problem that may prove very difficult to solve, because there is little distinct variation in budget rules across jurisdictions. This makes it virtually impossible to distinguish the effect of a number of particular budget rules in the United States states, because the set 
of states with one institution but not another is often very small.

The absence of information on detailed budget rules is an important limitation for advising policy makers, because actual debates hinge on precise rules. The existing literature cannot provide very helpful answers to questions such as how should a balanced-budget rule be enforced, or how high a supermajority requirement does one need to impose in passing revenue bills in order to hold down the growth of taxes.

Yet these shortcomings of the existing research should not detract from the substantial agreement that modifying the budget process can affect fiscal policy outcomes. The literature to date suggests that reforms that centralize power in a small set of budget actors, that increase the transparency of the budget process, and that make it more difficult to issue long-term debt are likely to reduce the level of government spending. Policies that are designed to reduce deficits in the U.S. states do appear to reign in the practice of rollingover short term debt and thereby using deficit finance. While these findings cannot be carried over completely to analyzing the case of federal budget policy in the United States, they create a presumption that altering the budget process can affect budget outcomes. 


\section{REFERENCES}

Abrams, B.A. and W.R. Dougan (1986). "The Effects of Constitutional Restraints on Government Spending." Public Choice 49, 101-116.

Advisory Council on Intergovernmental Relations (1987). Fiscal Discipline in the Federal System: National Reform and the Experience of the States. Washington: Advisory Council on Intergovernmental Relations.

Alesina, Alberto, and Roberto Perotti (1995a). "Budget Deficits and Budget Institutions." Mimeo, Harvard University.

Alesina, Alberto, and Roberto Perotti (1995b). "Fiscal Adjustment: Fiscal Expansions and Fiscal Adjustments in OECD Countries." Economic Policy 21 (October), 207-240.

Alesina, Alberto, Ricardo Hausmann, Rudolf Hommes, and Ernesto Stein (1995). "Budget Institutions and Fiscal Performance in Latin America." Mimeo, International Development Bank.

Alt, James E. and Robert C. Lowry (1994). "Divided Government, Fiscal Institutions, and Budget Deficits: Evidence from the States." American Political Science Review 88, 811-828.

Auerbach, Alan J. (1994) "The U.S. Fiscal Problem: Where We Are, How We Got Here, and Where We Are Going." In NBER Macroeconomics Annual, Volume 9, S. Fischer and J. Rotemberg, eds. Cambridge, MA: MIT Press.

Auerbach, Alan J. (1995). "Budget Deficits and Debt: Solutions for Developed Economics." In Federal Reserve Bank of Kansas City, Budget Deficits and Debt: Issues and Options. Kansas City: Federal Reserve Bank of Kansas City.

Auerbach, Alan J., Jegadeesh Gokhale, and Laurence Kotlikoff (1991). "Generational Accounts: A Meaningful Alternative to Deficit Accounting." In Tax Policy and the Economy. Volume 5, D. Bradford, ed. Cambridge, MA: The MIT Press, 55-110.

Bayoumi, Tamim, and Geoffrey Woglom (1995). "Do Credit Markets Discipline Sovereign Borrowers: Evidence from U.S. States." Journal of Monex Credit and Banking 27, 1046-1059.

Barro, Robert (1979). "On the Determination of the Public Debt," Journal of 
Political Economy 87, 940-971.

Bohn, Henning, and Robert P. Inman (1995). "Constitutional Limits and Public Deficits: Evidence from the U.S. States." Carnegie-Rochester Conference Series on Public Policy December.

Bunch, Beverly S. (1991). "The Effect of Constitutional Debt Limits on State Governments' Use of Public Authorities." Public Choice 68, 57-69.

Colm, G. and P. Wagner (1963), "Some Observations on the Budget Concept." Review of Econemics and Statistics 45, 122-126.

Crain, W. Mark, and James C. Miller III (1990). "Budget Process and Spending Growth." William and Mary Law Review 31, 1021-1046.

Dye, Richard F. and Therese J. McGuire (1995). "The Effect of Property Tax Limitation Measures on Local Government Fiscal Behavior." University of Illinois, Institute of Government and Public Affairs, mimeo.

Eichengreen, Barry J. (1992). Should the Maastrict Treaty Be Saved? International Finance Section Working Paper 74. Princeton: Princeton University.

Ferejohn, John and Keith Krehbiel (1987). "The Budget Process and the Size of the Budget." American Journal of Political Science 31, 296-320.

Gold, Steven D. (1992). "State Government Experience with Balanced Budget Requirements: Relevance to Federal Proposals." In U.S. House of Representatives, Committee on the Budget, The Balanced Budget Amendment: Volume 2, May 13 1992, 202-210.

Goldstein, Morris and Geoffrey Woglom (1992). "Market-Based Fiscal Discipline in Monetary Unions: Evidence from the U.S. Municipal Bond Market." In Establishing a Central Bank: Issues in Europe and Lessons from the United States, ed. M. B. Canzoneri, V. Grilli, and P. R. Masson. Cambridge: Cambridge University Press.

Gramlich, Edward M. (1990). "U.S. Federal Budget Deficits and GrammRudman-Hollings." American Economic Review 80: 75-80.

Hahm, Sung D., Mark S. Kamlet, David C. Mowery, and Tsai-Tsu Su (1992). "The Influence of the Gramm-Rudman-Hollings Act on Federal Budgetary 
Outcomes, 1986-1989." Journal of Policy Analysis and Management 11: 207-234.

Holtz-Eakin, Douglas (1988). "The Line Item Veto and Public Sector Budgets: Evidence from the States." Journal of Public Economics 36, 269-292.

Kiewiet, D. Roderick, and Kristin Szakaly (1996). "The Efficacy of Constitutional Restrictions on Borrowing, Taxing, and Spending: An Analysis of State Bonded Indebtedness, 1961-90." Journal of Law. Economics, and Organization (forthcoming).

Kotlikoff, Laurence J. (1986). "Deficit Delusion." The Public Interest 84: 5365.

Laibson, David (1994). "Self-Control and Saving." Harvard University, Department of Economics, mimeo.

Lowry, Robert C. and James E. Alt (1995). "A Visible Hand? Intertemporal Efficiency, Costly Information, and Market-Based Enforcement of Balanced Budget Laws." Harvard University Department of Government, mimeo.

Masia, Neal (1995). "Executive Power in the Budget Process: Evidence from the States." Washington: Congressional Budget Office.

Musgrave, Richard A. (1939). "The Nature of Budgetary Balance and the Case for the Capital Budget." American Economic Review 29, 260-271.

National Association of State Budget Officers (1992). State Balanced Budget Requirements: Provisions and Practice. Washington: National Association of State Budget Officers.

Organization for Economic Cooperation and Development (1995). Budgeting for Results: Perspectives on Public Expenditure Management. Paris: OECD.

Posen, Adam S. (1995). "Declarations Are Not Enough: Financial Sector Sources of Central Bank Independence." In NBER Macroeconomics Annual 1995, ed. B. Bernanke and J. Rotemberg. Cambridge: MIT Press.

Poterba, James M. (1994a). "American Fiscal Policy in the 1980s." In 
American Economic Policy in the 1980s, ed M. Feldstein. Chicago: University of Chicago Press.

Poterba, James M. (1994b). "State Responses to Fiscal Crises: The Effects of Budgetary Institutions and Politics." Journal of Political Economy 102, 799-821.

Poterba, James M. (1995a) "Balanced Budget Rules and Fiscal Policy: Evidence From the States." National Tax Journal 48, 329-337.

Poterba, James M. (1995b) "Capital Budgets, Borrowing Rules, and State Capital Spending." Journal of Public Economics 56, 165-187.

President's Commission on Budget Concepts (1967). Report of the President's Commission on Budget Concepts. Washington: U.S. Government Printing Office.

Preston, Anne E. and Casey Ichniowski (1991). "A National Perspective on the Nature and Effects of the Local Property Tax Revolt, 1976-1986." National Tax Journal 44, 123-146.

Reischauer, Robert D. (1990). "Taxes and Spending Under Gramm-RudmanHollings." National Tax Journal 43: 223-232.

Rueben, Kim S. (1995). "Tax Limitations and Government Growth: THe Effect of State Tax and Expenditure Limits on State and Local Government." Mimeo, MIT Department of Economics.

Riker, William (1980). "Implications for the Disequilibrium of Majority Rule for the Study of Institutions." American Political Science Review 74, 432446.

Shadbegian, Ronald J. (1996). "Do Tax and Expenditure Limitations Affect the Size and Growth of State Government?" Contemperany Economic Policy 14, 22-35.

Skidmore, Mark and James Alm (1994). "Voting on Tax and Expenditure Limitations." Northern Illinois University, Department of Economics, mimeo.

U.S. General Accounting Office (1985). Budget Issues: State Balanced Budget Practices, GAO Document GAO/AFMD-86-22BR. Washington: General 
Accounting Office.

U.S. General Accounting Office (1993). Balanced Budget Requirements: State Experiences and Implications for the Federal Government. GAO Document GAO/AFMD-93-58BR. Washington: General Accounting Office.

von Hagen, Jurgen (1991). "A Note on the Empirical Effectiveness of Formal Fiscal Restraints." Journal of Public Economics 44, 199-210.

von Hagen, Jurgen (1992). "Budgeting Procedures and Fiscal Performance in the European Communities." Economic Paper 96, Commission of the European Communities DG for Economic and Financial Affairs.

von Hagen, Jurgen and lan J. Harden (1995). "Budget Processes and Commitment to Fiscal Discipline." European Economic Review 39, 771 779.

Weingast, Barry R. and William J. Marshall (1988). "The Industrial Organization of Congress: or Why Legislatures, Like Firms, Are Not Organized As Markets." Journal of Political Economy 96, 132-163.

Weingast, Barry R., Kenneth Shepsle and C. Johnsen (1981). "The Political Economy of Benefits and Costs: A Neoclassical Approach to Distributive Politics." Journal of Political Economy 89, 642-664. 
56

Table 1: Federal Surpluses and Doficite (\% of GDP), 1950-1985

\begin{tabular}{|c|c|c|}
\hline Fiscal Year & Total Deficit & On-Budget Deficit \\
\hline 1950 & -1.2 & -1.8 \\
\hline 1951 & 1.8 & 1.4 \\
\hline 1952 & -0.4 & -1.0 \\
\hline 1953 & -1.8 & -2.3 \\
\hline 1954 & -0.3 & -0.8 \\
\hline 1955 & -0.8 & -1.1 \\
\hline 1968 & 0.9 & 0.6 \\
\hline 1857 & 0.8 & 0.6 \\
\hline 1958 & -0.6 & -0.7 \\
\hline 1959 & -2.7 & -2.5 \\
\hline 1960 & 0.1 & 0.1 \\
\hline 1961 & -0.6 & -0.7 \\
\hline 1962 & -1.3 & -1.1 \\
\hline 1963 & -0.8 & -0.7 \\
\hline 1964 & -0.9 & -1.0 \\
\hline 1965 & -0.2 & -0.2 \\
\hline 1968 & -0.5 & -0.4 \\
\hline 1967 & -1.1 & -1.0 \\
\hline 1968 & -3.0 & -3.3 \\
\hline 1969 & 0.4 & -0.1 \\
\hline 1970 & -0.3 & -0.8 \\
\hline 1971 & -2.2 & -2.5 \\
\hline 1972 & -2.0 & -2.3 \\
\hline 1973 & -1.2 & -1.2 \\
\hline 1974 & -0.4 & -0.6 \\
\hline 1975 & -3.5 & -3.7 \\
\hline $1976^{*}$ & -4.4 & -4.2 \\
\hline 1977 & -2.8 & -2.6 \\
\hline 1978 & -2.7 & -2.5 \\
\hline 1979 & -1.7 & -1.6 \\
\hline 1980 & -2.8 & -2.8 \\
\hline 1981 & -2.7 & -2.5 \\
\hline 1982 & -4.1 & -3.8 \\
\hline 1883 & -6.3 & -6.3 \\
\hline 1984 & -5.0 & -6.0 \\
\hline 1985 & -5.4 & -6.0 \\
\hline 1986 & -5.2 & -5.6 \\
\hline 1887 & -3.4 & -3.8 \\
\hline 1988 & -3.2 & -4.0 \\
\hline 1989 & -2.8 & -4.0 \\
\hline 1990 & -4.0 & -6.1 \\
\hline 1991 & -4.7 & -6.7 \\
\hline 1982 & -4.8 & -6.8 \\
\hline 1983 & -4.1 & -4.8 \\
\hline 1994 & -3.1 & -3.8 \\
\hline 1905 (est) & -2.7 & -3.0 \\
\hline 1896 (ost) & -2.7 & -3.5 \\
\hline 1997 (est) & -2.7 & -3.6 \\
\hline
\end{tabular}

Source: U.S. Office of Menegement and Budget, Historical Tebles: Budget of the United States Government, Fiscal Year 1996. 


\section{7}

Table 2: CBO Economic \& Technical Adjustments to the President's Budget

\begin{tabular}{lccc}
\hline Fiscal Year & Economic & Technical & Total Adjustments \\
\hline & 4 & 25 & 29 \\
1983 & -11 & -2 & -13 \\
1984 & 8 & 3 & 11 \\
1985 & 7 & -1 & 6 \\
1986 & 2 & \multicolumn{2}{l}{} \\
Average 1983-1986 & 2 & 6 & 8 \\
1987 & -1 & 17 & 16 \\
1988 & 15 & 12 & 27 \\
1989 & 25 & 11 & 36 \\
1990 & 10 & 17 & 27 \\
1991 & 9 & 30 & 39 \\
1992 & 26 & 44 & 70 \\
Average 1987-1992 & 14 & 22 & 36 \\
\hline
\end{tabular}

Source: Reischaver (1990) and author's calculations. 
Table 3: Distribution of Outlays by Budget Enforcement Act Category, 1965-1998 (Percentages of GDP)

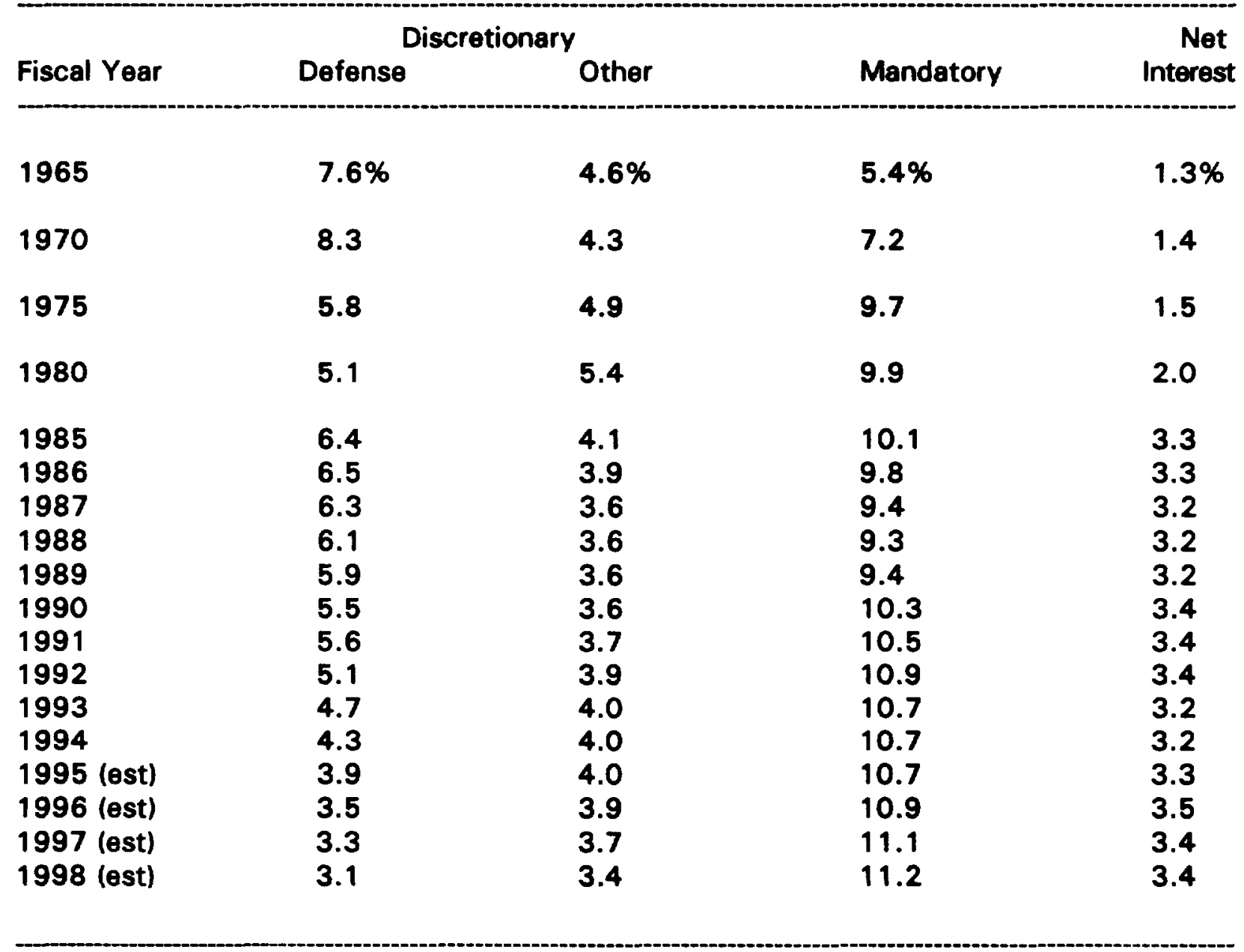

Source: U.S. Office of Management and Budget, Historical Tables: Budget of the United States Government, Fiscal Year 1996. 
59

Table 4: Distribution of Outlays by Budget Enforcement Act Category, 1965-1998 (Percentages of Total Outlays)

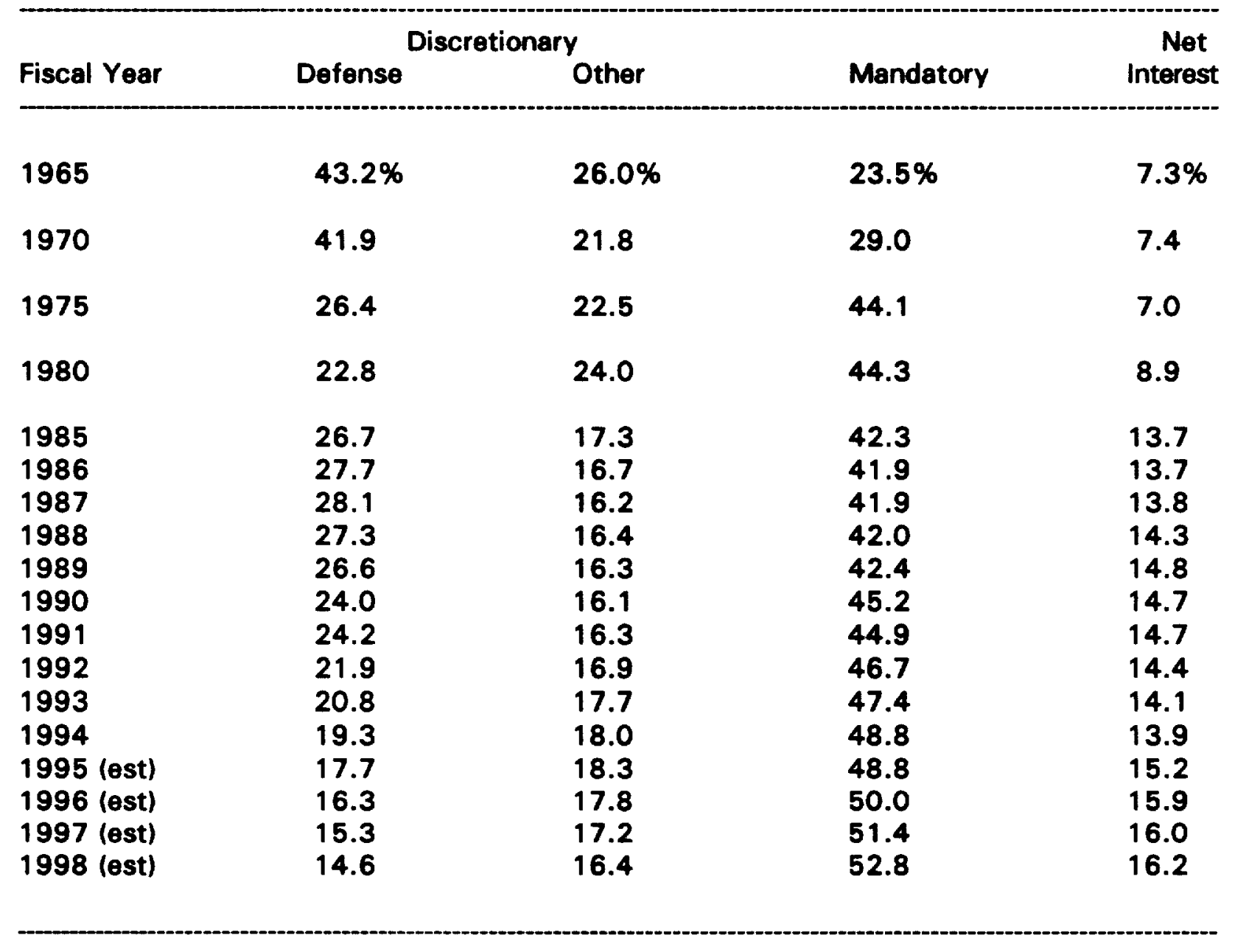

Source: U.S. Office of Management and Budget, Histerical Tables: Budaet of the United States Government, Fiscal Year 1996. 